\title{
Research
}

\section{How Participation Creates Citizens: Participatory Governance as Performative Practice}

\author{
$\underline{\text { Esther Turnhout }}^{1}, \underline{\text { Severine Van Bommel }}^{1}$, and $\underline{\text { Noelle Aarts }}^{2,3}$
}

\begin{abstract}
Participation is a prominent feature of many decision-making and planning processes. Among its proclaimed benefits is its potential to strengthen public support and involvement. However, participation is also known for having unintended consequences which lead to failures in meeting its objectives. This article takes a critical perspective on participation by discussing how participation may influence the ways in which citizens can become involved. Participation unavoidably involves (1) restrictions about who should be involved and about the space for negotiation, (2) assumptions about what the issue at stake is, and (3) expectations about what the outcome of participation should be and how the participants are expected to behave. This is illustrated by a case study about the Dutch nature area, the Drentsche Aa. The case study demonstrates how the participatory process that took place and the restrictions, assumptions, and expectations that were involved resulted in six forms of citizen involvement, both intended and unintended, which ranged between creativity, passivity, and entrenchment. Based on these findings, the article argues that participation does not merely serve as a neutral place in which citizens are represented, but instead creates different categories of citizens. Recognizing this means reconceiving participation as performative practice. Such a perspective goes beyond overly optimistic views of participation as a technique whose application can be perfected, as well as pessimistic views of participation as repression or domination. Instead, it appreciates both intended and unintended forms of citizen involvement as meaningful and legitimate, and recognizes citizenship as being constituted in interaction in the context of participation.
\end{abstract}

Key Words: citizenship; environmental governance; nature conservation policy; participation; performance; stakeholders

\section{INTRODUCTION: CITIZEN INVOLVEMENT IN NATURE CONSERVATION}

Processes of planning and decision making related to environmental issues and land use planning are increasingly characterized by attempts to involve the public. These intentions are often based on the perceived need to increase the legitimacy of the planning process and on the recognition that planning processes should involve those actors that are affected by them (e.g., Röling and Wagemakers 1998, Leeuwis and Pyburn 2002, Aarts et al. 2007, Lynam et al. 2007, Wollenberg et al. 2008).

Participation is considered beneficial because it can enhance learning processes, improve the quality of decisions, contribute to empowerment, or promote democratic citizenship (Innes and Booher 1999, Owens 2000, Cornwall 2002, Stringer et al. 2006, Ballard et al. 2008, Fernandez-Gimenez et al. 2008, Kuper et al. 2009). Very often, instrumental motivations play a role as well (Cornwall 2002, McCarthy 2005, Stringers et al. 2006, Chilvers and Burgess 2008). Based on a deficit model (Burgess et al. 1998, Bulkely and Mol 2003), participation is expected to lead to public support for planning decisions and, as a result, to effective and efficient implementation processes.

Current Dutch nature policy has clearly been inspired by these ambitions (Turnhout and Van der Zouwen 2010). While the 1990 policy plan was characterized by a top down approach (Aarts and Van Woerkum 1999) and a dominance of ecological expertise (Turnhout 2003), the current policy plan 
emphasizes the importance of public support and takes individual preferences and perspectives on nature into account. The motto and title of the plan "Nature for People, People for Nature" implies that if nature meets the demands of society and is accessible to and usable by people, they will take responsibility for it and contribute actively to its protection and management (LNV 2000).

Although both scientists and practitioners widely agree about the need for participation, little is known about how participation influences the way in which citizens can become involved. This article investigates what actually happens when ambitions regarding citizen involvement in nature conservation are put into practice. It asks how these processes involve people and what the intended and unintended consequences are.

This question is addressed by means of a case study on a Dutch nature reserve: the Drentsche Aa. The Drentsche Aa is an interesting and relevant case study because it provides an example of how the current ambitions for citizen involvement in nature conservation have been put into practice. Several participatory processes were set up in the area to guide the development and implementation of plans for designating the area as a national park. While the Drentsche Aa is often seen as a success story in terms of achieving citizen involvement (Van Bommel and Röling 2004, Van Bommel et al. 2009), this article argues that this is only part of the story. Our findings demonstrate that the participatory processes in the Drentsche Aa generated a wide variety of intended and unintended responses and outcomes, including deadlocked discussions, frustration, and disappointment.

This article contributes to the scientific debate about participation and its consequences by documenting the wide variety of responses identified in the case study and the different forms of citizen involvement that were achieved. Subsequently, this provides the basis for critical reflection on participation and for reconceiving participation as not merely representing citizens, but making them. As such, this article links up with the recent literature that discusses how participation influences citizen involvement (i.e., Aarts and Leeuwis 2010).

\section{PARTICIPATION AND CITIZEN INVOLVEMENT}

Participation and public involvement are promoted by planners, policy practitioners, and academics alike as a way to improve planning processes. Much attention has been paid to the different participatory methods and tools that are available and their strengths and weaknesses (for example, Van Asselt and Rijkens Klomp 2002, Lynam et al. 2007).

From early on, academics have distinguished between different forms of participation and have warned against a solely instrumental use of participation as a means of legitimizing previously established ends. Arnstein (1969) was critical of the lower rungs of her ladder of participation and warned about manipulation, therapy, and tokenism. According to Arnstein (1969), "real" participation could be found only on the higher rungs of her ladder. In a similar vein, Goodwin (1998) distinguishes between "hired hands" and "local voices" in the context of nature conservation. While these distinctions are useful, they are also overly simplistic and fail to recognize the multidimensional character of participation (Chess and Purcel 1999, Webler and Tuler 2002). A good illustration of this is given by Lawrence (2006), who uses the example of volunteer recorders who, despite being involved "only" on a low level of participation, gained a genuine sense of involvement and empowerment.

Increasingly, the academic debate about participation is moving away from questions of different kinds of participation and ways to organize them towards the actual effects of participation in practice. This orientation on practices of participation has provoked a wide array of critical studies that have investigated the intended and unintended consequences of participation, and question whether the various ideals of participation, including consensus, better decisions, legitimacy, and support are actually met. In most of these studies, such failures are attributed to participation being organized in the wrong way, for example, designed in ways that are inappropriate for the local context and issue at stake (e.g., Dietz and Stern 2008). Other studies, inspired by post-structuralist conceptions of power, take a more fundamental stance and conceive of participation as yet another technique to exert control over local inhabitants and as a new form of colonial oppression (i.e., Cooke and Kothari 2001). 
These studies make a very important contribution to the scientific debate about participation because they focus the attention on how participation is much more than just a neutral place where citizens can make themselves heard and represent themselves. Conceptions of what citizens are and how they are supposed to behave are deeply implicated in how participation is organized and put into practice (Leach et al. 2005). Thus, participation influences how citizens can become involved and be represented. This is relevant in light of the objective of this article to understand the different ways in which citizens respond to participatory initiatives and the different forms of citizen involvement that are achieved by participation. We use the term "citizens" not in a narrow way to refer to "the general public" but in a broad way that includes all members of a particular community as possible participants, including so-called representatives and stakeholders. The issue at stake is how individuals become involved, how they enact their citizenship in practice, and how that is affected by the context of participation.

The following overview presents different, but related, common experiences in which participation influences the ways in which citizens can become involved. All result in boundaries, restrictions, and limitations. We do not present these as a complete overview of experiences with participation. However, studies of participation that have resulted in such critical reflections are underexposed in the scientific literature. More importantly though, a discussion of how participation structures and restricts citizen involvement suits the purpose of this article, which is to understand why and how participation may lead to unintended consequences and why it sometimes fails to meet its objectives. This article focuses on how participation creates citizens rather than offering a neutral space in which they can represent themselves. A discussion of these performative effects of participation is provided in the conclusion of this article.

\section{Participation includes some and excludes other citizens}

Although participation is often inspired by the desire to open up decision-making processes to wider audiences, it is clear that it is impossible to involve everybody and that representation can never by complete (O'Neill 2001). Participation is inevitably selective when it comes to who is able to participate. Some individuals recognized as relevant participants are considered to be part of the citizenry, while those excluded are left without a voice, without a way to express their involvement and enact their citizenship.

\section{Participation represses differences and requires citizens to achieve consensus}

Many participatory processes explicitly aim for consensus because this is considered to be a robust basis for high quality and legitimate decisions (Innes and Booher 2004). However, consensus comes at a cost: "it can create a false sense of closure and the illusion of stability" (Bloomfield et al. 2001:503). Mosse (2001) argues that the aim to achieve consensus easily leads to implicit pressure to exhibit conformist behavior. This can lead to the emergence of groupthink, a mode of thinking in which 'the members' strivings for unanimity override their motivation to realistically appraise alternative courses of action" (Janis 1972:9). Diversity in perspectives is thus suppressed. The notion of community that is used in participation further adds to this. Participation can treat local communities as homogenous units with common perspectives and interests, thereby overlooking the problematic character of defining communities and community interests (Selfa and Endter-Wada 2008) and suppressing intra-community diversity and difference (Mohan and Stokke 2000). Pre-existing commitments to achieve consensus thus influence how citizens can become involved and what they are expected to do. A risk exists that they become committed to achieving consensus and are assimilated into the process to such an extent that they loose sight of their original motivations for participating.

\section{Participation reinforces dominant frameworks and expects citizens to accept them}

In terms of problem definition and space for negotiation, participation is often restricted right from the start (e.g., Gonzalo-Turpin et al. 2008). For example, it may involve choosing between predeveloped policy alternatives or scenarios or developing solutions for predefined problems. While these existing problem definitions or alternatives often remain unquestioned, they shape participatory processes in important ways. As a result, existing dominant frameworks are 
reproduced and reinforced (Wagemans 2002). Because "participatory approaches and methods also serve to represent external interests as local needs, dominant interests as community concerns, and so forth" (Mosse 2001:22), powerful interests are strengthened and empowerment of participants is often not achieved (Stringer et al. 2006). Participation assimilates the participants and incorporates them into the projects of the already powerful. In this sense, participation is little more than a new technique with which, under the veil of inclusivity, existing goals can be reached in effective and newly legitimated ways (Kabeer 1996, Parfitt 2004). Thus, pre-existing definitions of problems influence citizen involvement because they structure and restrict the possible outcomes of participation and influence what citizens can and cannot do.

\section{Participation excludes citizens without the required knowledge and skills}

The extent to which meaningful participation is possible depends largely on the specific capacities and skills of the participants (Wagemans 2002). Expressing your views and representing your interests in an effective and meaningful way within dominant frameworks requires not only knowledge of these frameworks but also communicative skills, creativity, and guts. And not everybody possesses those equally: "[the] capacity to say and to be heard are unevenly distributed" (O'Neill 2001:484; also see Kohn 2000). Under the veil of Habermasian ideals of communicative rationality and the superiority of "the best argument", technical, scientist, and elitist discourses often dominate participatory processes, effectively silencing those who are uncertain about their capacity to join these discussions (Goodwin 1998, Pellizzoni 2001). Participation can certainly contribute to developing those capacities (Dietz and Stern 2008). However, if this aspect is neglected, participation runs the risk of excluding those citizens who lack those capacities, rendering them unable to become involved and be heard.

\section{Participation implies a limited conception of citizenship}

Participatory initiatives are imbued with expectations about what the participants should do and how they should behave, and this influences how citizens can become involved. Often, citizens are invited because they are seen as stakeholders: people who are perceived to hold a particular stake in the issue and are expected to represent it. Such a preconception leaves little room for citizens to change their preferences and interests. As such, it sits uncomfortably with the ambitions for achieving consensus and for collective decision making (Hendriks et al. 2007). These expectations can even prime participants to hold on to their interests to the extent that participatory processes reach a deadlock. Inviting citizens as stakeholders limits them in the identities they can put forward and the views and preferences they can articulate. This observation ties in with Leach and Scoones (2005), who show how different conceptions of citizenship (liberal, republican, or communitarian) are linked to specific expectations of and approaches to participation. This means that "participatory approaches 'afford' certain subject positions to the participants, and thus, [...] presuppose and shape 'participants' from the very beginning" (Henkel and Stirrat 2001:179).

Although there are cases of participation that have resulted in empowerment, capacity building, legitimacy, and better decisions (Dietz and Stern 2008), it is important to recognize that restrictions and limitations, such as the ones discussed above, are unavoidably connected to any participatory practice. Indeed, it is difficult to think of participation as having no preconceptions about the issue at stake, the expected outcomes, and who to involve. Consequently, these cannot be prevented through better techniques or better applications. This is the main reason for Cooke and Kothari to make their case for participation as tyranny: "participatory development's tyrannical potential is systemic, and not merely a matter of how the practitioner operates or the specificities of the techniques and tools employed" (Cooke and Kothari 2001:4).

The important question is not whether participation is exclusive, selective, and restricted, but how it is. Which types of exclusion are achieved - not just in terms of who is in and who is out, but also in terms of the identities, perspectives, and views that can legitimately be included in participation. Consequently, this article addresses the following question: What different intended and unintended forms of citizen involvement are achieved when participation is organized to achieve citizen involvement? 


\section{CASE STUDY AND METHODS}

The Drentsche Aa area is located in the north of the Netherlands (Fig. 1). It is renowned for its wellpreserved brook system, which contains many rare plants (including many orchids). In addition, the area is unique in terms of landscape and cultural history: it is one of the few areas in the Netherlands that survived large-scale agricultural modernization and land consolidation. The landscape is characterized by picturesque villages and smallscale agricultural elements, such as hedgerows and elevated arable fields, which resulted from centuries of using heather sods mixed with cattle manure to fertilize the arable fields.

Most of the brook meadows are owned by the Dutch State Forest Service, which is responsible for their conservation. Scientific studies had shown that the meadows were degraded because the groundwater that infiltrates the area was polluted by the intensive agriculture that takes place on the higher plateaus. Based on those findings, the State Forest Service came to see intensive agriculture as a major threat to the area's conservation values.

From the 1970s to early 1990s, policies for the Drentsche Aa had, for the most part, been based on protecting the area's unique landscape features and on offering room for economic development (mostly tourism and agriculture). Nature conservation, per se, was not so prominent. However, this changed in 1993 when the preliminary Dutch preparatory committee for national parks recommended that the Drentsche Aa be designated as a national park. This was fiercely resisted by local farmers. They feared for their livelihoods and they criticized the process for being a form of outside interference and for being elitist and expert-driven (Van Bommel and Röling 2004). The committee realized that this lack of support endangered the plans to create a national park. Consequently, the committee recommended initiating participatory processes. They believed that participation would be able to remove the existing objections and generate support for the national park.

In 1999, government officials decided to install a multi-stakeholder platform to negotiate the design and management of the Drentsche Aa area. The platform was set up first to achieve consensus about developing plans for a national park in the Drentsche Aa area, and second to guide the implementation of those plans. With the aim to involve all stakeholders, government officials invited representatives of the Ministry of Agriculture, Nature and Fisheries, the Province of Drenthe, the State Forest Service, the Farmers' Union, the Brede Overleggroep Kleine Dorpen ([BOKD] an organization that represents the interests of the small villages), and the tourist industry to participate in the platform. Also, outside of the multi-stakeholder platforms, participation was organized in the form of information and discussion meetings. These meetings offered an opportunity for those not included in the platform to have their say.

When the participatory processes started, the policy context in the Drentsche Aa had changed. In 1998, a new national Nature Policy Plan had been adopted, which designated the area as one of the core areas in the ecological network that was to be established. Thus, although they continued to leave room for agriculture and other forms of economic development, existing policies for the Drentsche Aa had moved in the direction of nature conservation. This proved to be a crucial factor in the multistakeholder platform because right after it started, a letter was sent by the national government which stipulated that the outcomes of the platform had to fit with these existing policies. The participatory processes thus took place with considerable animosity between the State Forest Service and the farmers, in a context in which newly adopted policies had shifted in favor of nature conservation, and in which the scope for negotiation turned out to be more limited than anticipated.

The results presented in this article cover the period between 1999, when the participatory processes started, and the end of 2005. This period includes the development and adoption of plans for the creation of a national park, as well as the first steps of their implementation. The analysis presented is part of a larger study into the Drentsche Aa, parts of which have been previously published in Van Bommel (2008), which contains an elaborate methodological chapter, and in Van Bommel et al. (2009), which focuses on social learning. The material presented in this article is from three main sources: transcripts of 70 open interviews, transcripts of 12 multi-stakeholder meetings, and 75 relevant documents. The 70 interviews were conducted with local farmers (11), villagers (16), policy makers from the regional government (10), representatives from nature conservation organizations (10), representatives from farming organizations 
Fig. 1. Location of the Drentsche Aa area (http://www.nationalelandschappen.nl/).

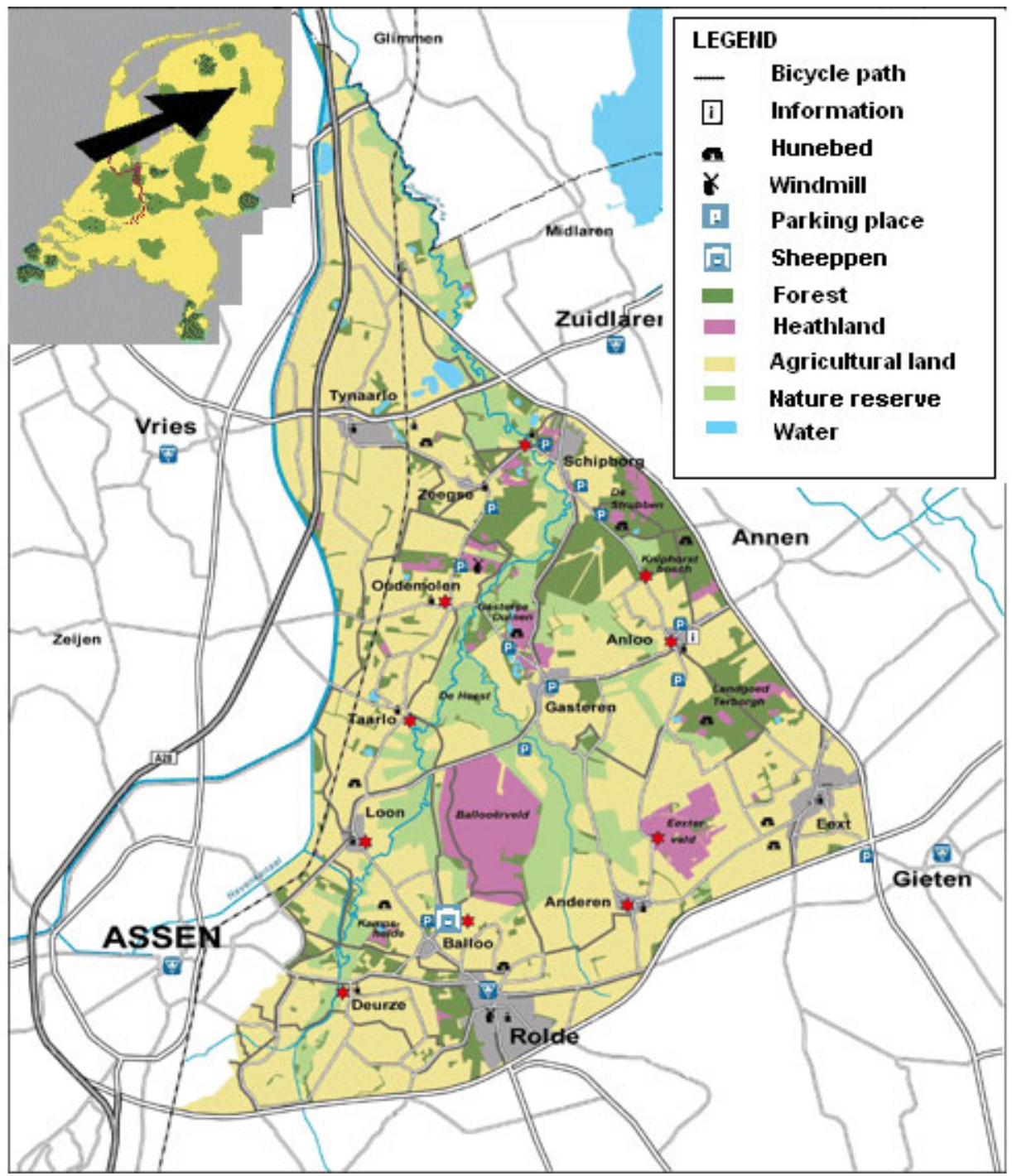

(2), involved scientists (5), and other actors (16). Taken together, the interviews included the major players in the area and covered the variety of perspectives present. The interviews generally took between 1 and 2 hours to complete, and were in the form of semi-structured conversations. A checklist of topics and questions was used to invite the respondents to talk about their ideas and experiences regarding the plans for the Drentsche Aa, the identity and future of the area, the multi-stakeholder platform, and the information and discussion meetings. Also, the respondents were invited to bring up other topics that they felt were interesting and relevant.

\section{RESULTS: CITIZEN INVOLVEMENT IN THE DRENTSCHE AA}

This section reports on the different responses generated by the installation of the multistakeholder platform in the Drentsche Aa. It presents six different forms of citizen involvement. This classification is neither intended as a complete 
overview of possible responses to participation, nor is it an attempt to classify individuals. Although, there may be a fit between actual people and the way in which they were involved as citizens, our classification allows for individuals to be involved in multiple ways. The six categories serve to structure the analysis, to order the forms of involvement identified in the case study, to show their diversity, and to describe the dynamics between them.

\section{Interest representing citizens}

The participatory process in the Drentsche Aa was based on the assumption that all relevant stakeholders should be included. The use of the word "stakeholder" suggests a specific framing of the issue. It makes clear that the initiators of the platform not only recognized that different stakes and interests were involved that needed to be represented, they also knew what these stakes and interests were and who held them. The term "stakeholder" also comes with expectations about what the participants should do and how they should behave. The participants in the platform were expected to represent their interests, not to protect them at all costs. They were expected to deliberate together about how the different interests could be balanced and how to achieve a compromise.

Initially, the different participants acted as interest representatives; they had a clear idea about what their interests were and how to represent them. The representative of the Farmers' Union wanted to ensure there was enough room for intensive agriculture, the BOKD representative wanted to preserve the cultural history and identity of the area, and the representative of the State Forest Service wanted to protect the biodiversity and conservation values of the area. In addition, the constituencies of these representatives were invited to become involved by participating in information and discussion meetings. During these meetings, they could ask questions, share their perspectives, and take a look at the plans. In response to the question of why he visited those meetings, one of the participants explained:

If things are about to happen and they're written down on paper, then it is important to be involved as a village. Things happen all around us. If you don't participate as a village, then don't blame others if things don't go as expected. What do you want your village to look like in the future? That's the question. If you're given the opportunity to do something, then do it! That's my point of view. (Villager from Anloo, 14 June 2005, Anloo).

Within the platform, the representative of the BOKD played an important role as interest representative. He presented his ideas for the areas as follows:

When dealing with conservation and development of landscape values and ecological values in the Drentsche Aa area, it is wise to focus our attention on identity[...]. This has to do with the regional specific characteristics and developments that together give the area its specific character.[...] We can convincingly speak of a 'living landscape' that has been able to keep hold of its identity throughout time and constant change. [...] In the identity strategy, we will consciously deal with the intrinsic dynamics, and changes will be linked to an active conservation policy. In short, the identity strategy relies on the motto 'conservation through renewal' (Representative of the BOKD, 9 July 1999, platform-meeting in Assen).

The BOKD representative emphasized the importance of the area's unique identity and cultural history. He used the notion of "conservation through renewal" as a crucial element in his vision. This fitted well with the existing policy framework, which emphasized conservation, cultural history, and multi-functional agriculture. The notion of "conservation through renewal" was of crucial importance because it could potentially unite farmers and nature conservationists. It offered room for agriculture as well as nature conservation, both of which were considered to be important activities in shaping the landscape and identity of the Drentsche Aa area. Because they fitted so well with the policy context and because they had the potential to unite agriculture and nature conservation, the ideas of the BOKD representative turned out to be very influential in the multi-stakeholder platform.

Thus, the platform came with restrictions related to the behavior of the participants: they were expected to behave as interest representatives, willing to represent their interests, balance the different interests, and reach compromise. However, soon after the installation of the platform, it became clear that there were restrictions on the space for negotiation; the outcomes had to fit with existing policies on which the participants had had no 
influence. These restrictions had a major impact on the dynamics within the platform because, as it turned out, the role of interest representative proved difficult to maintain.

\section{Entrenched citizens}

The notion of "conservation through renewal" potentially offered room for agriculture, but the question was what kinds of agriculture would be acceptable. It remained unclear whether it referred only to small-scale, multi-functional agriculture, or whether intensive agriculture would also be allowed. Subsequently, a discussion emerged about the room for agriculture in the Drentsche Aa. The representative of the Farmers' Union was worried that the new plans would not offer enough room for intensive agriculture:

We need much more discussion with regard to agriculture in the Drentsche Aa region. At present, [the plans for the Drentsche Aa] focus mainly on sustainable agriculture and assume that intensive agriculture is not feasible. This does not fit with the way that my constituency is experiencing the situation (Farmers Representative, 8 October 2001, platform meeting, location not specified).

The representative of the Farmers' Union was very aware of the fact that the farmers who remained in the area were completely dependent on exports and hence on competitiveness within Europe, where all farmers had equal access to subsidies. He wanted farms that could adapt to the demands of that market without being hampered by regulatory frameworks to protect nature. Also, he did not want farmers to become dependent on subsidies in exchange for nature conservation and management services. The representative of the State Forest Service felt threatened by these insistent demands for space for intensive agriculture. The unique conservation values of the area and its turbulent conservation history had instilled a strong awareness within the State Forest Service of the vulnerability of the area under their responsibility. Intensive agriculture was seen as a major threat, and according to the State Forest Service representative, any compromise with the farmers to allow intensive agriculture implied the immediate destruction of the rare water meadow flora:

Nature is negatively influenced...by the intensive [agricultural] land use on the higher grounds. That situation is unacceptable. The Drentsche Aa area is an extraordinary landscape, and in the past, a fundamental choice was already made to conserve $i t$. We should stand by that decision and accept its consequences (State Forest Service representative, 9 January 2003, Assen).

The debate ran into a deadlock. The representatives of the Farmers' Union and the State Forest Service both assumed uncompromising and inflexible attitudes, and there was no space to talk about balancing interests or reaching a compromise. They were no longer acting as interest representatives but became entrenched. And this threatened the progress within the multi-stakeholder platform.

\section{Assimilated citizens}

The debate between the representatives of the Farmers' Union and the State Forest Service did not fit with the expectations of the initiators of the multistakeholder platform. According to the chairman:

Multi-actor negotiation requires participants to have certain qualities. I do not see much of those qualities in either the nature conservation representatives or in the farmers' representatives, and that worries me. [...] The farmers representative here has a one-track view. [...] I am going to tell him that he should reconsider whether he is the right person to represent the agricultural sector on this platform, and if we want to continue like this. But what applies to the farmers also applies to the nature conservationists. Therefore, I have asked the State Forest Service to replace their current representative if he does not display a more cooperative attitude (Chairman of the Deliberation Committee, 6 December 2005, Groningen).

The chairman threatened to replace the representatives if they did not change their attitude. And it worked: the representative of the Farmers' Union became convinced that it was in his best interest to stop fighting, accept that the space for intensive agriculture had been restricted right from the start, and go with the flow. The representative of the State Forest Service was replaced by a more accommodating and cooperative one. By now, all the participants in the multi-stakeholder platforms became deeply assimilated into the process itself. They became very committed to achieving results, to such an extent that representing their interests, which they were invited to do, became less important. 
This ensured progress in the platform, and on 4 December 2002, the Drentsche Aa area was formally designated as a national landscape. ${ }^{[1]}$ However, there were also downsides. Some representatives were "assimilated" by the process to such an extent that they started to conceive of the dominant vision in the platform as the only logical and reasonable one. As a result, they lost touch with their constituencies, whose interests they were expected to represent. This became especially clear when looking at how citizens responded to the information and discussion meetings.

\section{Disappointed citizens}

Some citizens wanted to be involved and attended the discussion and information meetings. However, they were disappointed because they had the impression that everything had already been decided and that nobody was really interested in their views and ideas:

Everything has already been decided and [...] afterwards we are allowed to discuss it (Villager from Anloo, 10 August 2005, Anloo);

During one of the first discussion meetings that I joined, a provincial official told me "we will implement our policy plans anyway'. That is what he told me to my face (Villager from Tynaarloo, 11 August 2005, Tynaarloo).

As a result, these citizens stopped coming to the meetings because they did not feel that it was useful:

I think people are thinking and talking about [the plans]. But people do not go to meetings anymore because nothing good ever comes out of them (Villager from Anderen, 21 September 2005, Anderen);

The people in the villages are quite skeptical with regard to the national landscape. The national landscape officials try to involve them in all kinds of things, but people just don't attend these activities.[...] It's all talk, talk, talk (Villager from Anloo, 14 June 2005, Anloo).

The people quoted here were interested in nature and landscape policy but they became disappointed. They felt that the multi-stakeholder platform did not intend to give them a say and did not appreciate their input. A passive response -to stop attending the meetings - was the only option left for them.

\section{Disinterested citizens}

Passivity resulted not only from disappointment but also from a lack of interest in participation. In part, this was based on a different perspective on the area. Some people did not see the need for new plans. They did not feel that nature and landscape were really issues worthy of so much attention, and they did not share the concerns of the initiators of the multi-stakeholder platform regarding conservation of the biodiversity and natural values of the area. These two people told us:

The people from the national landscape see this as a nature reserve, but then a nature reserve with historic villages in it. We don't share that perception. [...] We just want a village that's pleasant to live in (Villager from Anloo, 10 August 2005, Anloo);

This biodiversity that everybody is worried about... I don't think I really see [what] they are talking about. [...] Orchids are just weeds here [...] what is so special? There are millions of them (Villager from Anloo, 23 September 2005, Anloo).

They remained passive because they were not interested in participating. This makes it clear that there was a mismatch between how the initiators of the platform and some of the villagers defined the problem.

\section{Creative citizens}

After the plans for the Drentsche Aa had been established, citizens were invited to contribute to the implementation of the plans by submitting their own projects. Creative citizens used this opportunity to initiate new activities and connect the plans to their ideas. Ideas to generate income were framed as projects that contributed to the implementation of the plans, even when they did not fit perfectly with existing policies. Increased tourism, for example, offered opportunities to start small-scale businesses that served the demands of the visitors:

I used to have a potato farm. I have now created a forest on my land and started a camping site. The forest is subsidized for the coming 20 or 30 years. The camping site is big enough to be profitable (Rural entrepreneur, 21 June 2005, Anderen).

In a similar vein, other farmers initiated projects aimed at selling regional products or opening up 
their farms to visitors. Some farmers redesigned their methods in such a way that they fitted in with the policy frameworks and complied with regional nature and landscape policy in creative ways. For example, local farmers entered into tenure arrangements with the State Forest Service to meet the criteria of the Manure Act:

Dairy farmers like to be tenants of the State Forest Service because if you're a tenant, you can use that land to compensate for the manure that you produce on your farm. According to the Manure Act, you are allowed to own three cows per hectare. You can also use the land under tenure contracts for your manure bookkeeping. The State Forest Service land just gives you more bookkeeping freedom (Farmer from Grolloo, 22 September 2005, Grolloo).

These examples show that some people found creative ways of using the existing rules and regulations to their advantage. They changed or redefined their practices to make them fit in with existing policies and procedures while at the same time generating income. These creative citizens were not passive recipients of plans and policies but co-created them in unexpected and innovative ways. However, it is clear that this was not easy. Creative citizens needed to have knowledge about not only existing policies and rules but also the negotiation space afforded by them. Also networking and communication skills were necessary to enable creative citizens to work within and around the existing frameworks and use them to their advantage.

\section{DISCUSSION: CREATING CITIZENS?}

The different forms of citizen involvement outlined in the previous section shows that the initiative to organize participatory processes in the Drentsche Aa area has triggered multiple responses. Some of these were intended: people were invited to the multi-stakeholder platforms and the discussion and information meetings as interest representatives. Also, creative citizens were invited to contribute to the implementation of the plans by formulating and submitting their own projects. The other four unintended forms of citizenship were created in the context of participation.

The stakeholders in the platform and their constituencies who were invited to join the information and discussion meetings were expected to behave as interest representatives by making themselves heard and representing their views and interests. Also, they were expected to be willing to balance the different interests and reach a compromise. However, this role proved difficult to maintain. The restrictions put on the platform regarding how the participants were expected to behave and the space for negotiation resulted in the entrenchment of some participants. Inviting participants because they were stakeholders made them express this identity forcefully. They did not merely represent their interests; they protected them and refused to compromise. In doing that, they moved away from interest representatives to entrenched citizens. The requirement that the outcomes of the platform had to fit with existing policies added to this. It triggered strong reactions from those participants whose views deviated from the dominant vision for the area. As a result, the process in the multi-stakeholder platform ran into deadlock. For the sake of progress, the chairman threatened to replace the entrenched citizens, and in fact ended up replacing one of them. The remaining entrenched citizen was pressured into changing his attitude and committing to the multi-stakeholder platform. Subsequently, the members of the multistakeholder platform became assimilated into the process at the expense of their link with their constituencies.

The paradoxical conclusion that follows from this is that apparently, progress in a multi-stakeholder platform depends on the extent to which the invited participants deviate from what they were invited to do - that is, to represent their interests. As a result, multi-stakeholder platforms run real risks of losing touch with their constituencies, of increasing the gap between government and citizenry, and of enhancing the problem they were intended to solve. This resonates with other studies of participatory processes that have pointed to paradoxical outcomes of participation (Hajer and Kesselring 1999, Innes and Booher 2004, Chilvers and Burgess 2008, Aarts and Leeuwis 2010).

Outside the platform, meaningful participation was possible only for citizens who either had the persistence to represent their interests and express their resistance, or were creative enough to work within and around the existing frameworks and submit their own ideas and projects. The others took on a passive attitude. In the case study, we encountered two categories of passive citizens: the disappointed citizen and the disinterested citizen. 
Although homogenous in terms of behavior, the two categories differ with respect to the reasons and motivations for their passive behaviors. Disappointed citizens were interested in the plans for their area and in participating in the policy process but became disappointed with their opportunities for meaningful participation. Disinterested citizens were passive because they did not see the need for active participation: their problem definitions differed from those of the initiators and they did not identify with the plans or perceive them as relevant.

Passive behavior can thus emerge for radically different reasons (a point also made by McComas et al. 2006). These differences are neglected by the common conception of citizens as passive recipients of policy. Often, passive citizens are mistakenly seen as a homogenous group of people who apparently are not interested in active participation and are only require to be informed. Clearly, this view is not adequate (also see Goodwin 1998). Passive citizens could become involved in the participatory process if it is organized in a more open way - for example, if it allows for open discussions about the space for negotiation, the nature and definition of the problem, and the relevance of the plans for the inhabitants. Because the participatory processes in the Drentsche Aa failed to do each of these, people were either not interested in participating or became frustrated.

The main finding of the case study is that participatory initiatives in the Drentsche Aa area have resulted in a wide variety of responses in terms of both intended and unintended forms of citizen involvement. In terms of creating citizens, it may seem that the expectations of the initiators of participation have only partially been realized. They asked for interest-representing and creative citizens but got much more than they asked for. Our analysis makes it clear that the unintended forms of citizen involvement were also created in the participatory processes.

\section{CONCLUSION: PARTICIPATION AS PERFORMATIVE PRACTICE}

The case study exemplifies many of the criticisms of participation described earlier. The participatory processes in the case study were characterized by limited and static conceptions of citizenship. Because of the dominance of existing policies, the multi-stakeholder platforms achieved little more than their reproduction. Shifts in power relations and empowerment of the local inhabitants were not achieved. Instead, the process contributed to the reinforcement of already powerful interests. Furthermore, it is clear that meaningful participation was not easy and required specific knowledge and skills.

Such an analysis, however, neglects the active contributions of the participants and the ways in which participation is also a "resource for human agency" (Kesby 2007). Mosse (2001) and White (1996), for example, describe how the ways in which local people articulated their local needs were influenced by their expectations of what the agency could deliver. Participation thus involves not so much the representation of pre-existing local perspectives, views, or interests, but their construction in the context of participation: "Through [participation] 'local knowledge', far from modifying project[s], is articulated and structured by them" (Mosse 2001:24). Thus, participation can open up possibilities for strategic action and create space for renegotiation and reinterpretation (Nuijten 1992, Goodwin 1998).

Reconciling post-structuralist critique with human agency (Kesby 2007) means recognizing the performative dimension of participation (Hajer 2005). The implications of performativity can be clarified by the use of theater metaphors (as introduced by Goffman [1959] and applied for example by Kothari [2001]): participatory practices are seen as staged performances in which the various actors, based on the script, the instructions of the director, and their improvisation skills, play their parts. Conceiving of participation as a performative practice emphasizes that identities, knowledge, interests, and needs are not represented but shaped, articulated, and constructed in the participation process itself. Participatory practices involve context-specific interactions between participatory initiatives and the expectations they are imbued with on the one hand, and participants and the needs, identities, and views they articulate on the other.

Although it remains important to analyze exactly how participatory processes create their own participants and with what consequences for citizen involvement, as we have done in this article, it is now clear that such an account is incomplete. The forms of citizen involvement identified in the case study are best regarded as articulations resulting from context-specific interactions and practices. 
This is consistent with contemporary ideas on citizenship as expressed, among others, by Mouffe (1993:12): "No identity is ever definitively established, there always being a certain degree of openness and ambiguity in the way [it is] articulated." Citizenship in that way is not an apriori given but is constructed in interaction in the context of participation. Or, as Leach et al. (2005:29) put it: "citizenship [should be understood] as practised engagement through emergent social solidarities".

A perspective of participation as performative practice goes beyond current optimistic debates about participation as a normative ideal that concentrates on the correct or incorrect application of techniques and methods. It also goes beyond the merely critical view of participation that emphasizes dominance, repression, and control. It makes it clear that participatory processes are practices that inevitably require acting, choosing, and selecting, in which expectations of participants and initiators interact, and in which forms of involvement, identities, and interests are articulated. This means that unintended consequences of participation are inevitable. Participation will always be exclusive in some way. It will come with restrictions about the scope of negotiation and who should be involved, with assumptions about the issue at stake, and with expectations about the outcome of the participatory process and what the participants should do and how they should behave. It is important to not only acknowledge this but also critically reflect on which restrictions, assumptions, and expectations are present, how they affect citizen involvement, and what kinds of exclusion are achieved and with what implications.

We wish to promote a reflexive view of participation as performative practice, which takes into account the intended and unintended consequences of participation in terms of inclusion and exclusion and examines the implications of these achievements for citizenship, governance, and democracy. Such a perspective recognizes that participatory initiatives will generate a variety of intended and unintended responses and considers both the initiators and the participants as actors in the sense that they act and shape participatory processes.

As our analysis demonstrates, organizing participatory processes is an endeavor with fundamentally unpredictable outcomes. Although such a lack of control may be uncomfortable for planners and organizers, unpredictability is also an opportunity for the emergence of new perspectives and ideas. From this perspective, unintended forms of citizen involvement are not to be discarded as solely resulting from either illegitimate repression or control or from the wrong application of a fundamentally good method. Instead, both intended and unintended responses will have to be recognized and appreciated as meaningful forms of citizen involvement.

Responses to this article can be read online at: http://www.ecologyandsociety.org/voll5/iss4/art26/ responses/

\section{Acknowledgments:}

This research has been supported by the Netherlands Ministry of Agriculture, Nature and Food Quality in the "Kennisbasis" research programme of Wageningen University and Research Centre.

\section{LITERATURE CITED}

Aarts, N., and C. Leeuwis. 2010. Participation and power: reflections on the role of government in land use planning and rural development. Journal of Agricultural Extension and Education 16:131-145.

Aarts, M. N. C., and C. M. J. van Woerkum. 1999. Communication and nature policies: the need for an integral approach to policy design. Pages 33-48 in C. Leeuwis, editor. Integral design: innovation in agriculture and resource management. Mansholt Institute/Backhuys Publishers, Wageningen, The Netherlands.

Aarts, N., C. van Woerkum, and B. Vermunt. 2007. Policy and planning in the Dutch countryside: the role of regional innovation networks. Journal of Environmental Planning and Management 50:727744.

Arnstein, S. R. 1969. A ladder of citizen participation. Journal of the American Planning Association 35:216-224.

Ballard, H. L., M. E. Fernandez-Gimenez, and V. E. Sturtevant. 2008. Integration of local 
ecological knowledge and conventional science: a study of seven community-based forestry organizations in the USA. Ecology and Society 13:37. [online] URL: http://www.ecologyandsociety. org/vol13/iss2/art37/.

Bloomfield, D., K. Collins, C. Fry, and R. Munton.2001. Deliberation and inclusion: vehicles for increasing trust in UK public governance? Environment and Planning C 19:501-513.

Bulkeley, H., and A. P. J. Mol. 2003. Participation and environmental governance: consensus, ambivalence and debate. Environmental Values 12:143-154.

Burgess, J., C. Harrison, and P. Filius. 1998. Environmental communication and the cultural politics of citizenship. Environment and Planning A 30:1445-1460.

Chess, C., and K. Purcell. 1999. Public participation and the environment: do we know what works? Environmental Science and Technology 33:2685-2692.

Chilvers, J. and J. Burgess. 2008. Power relations: the politics of risk and procedure in nuclear waste governance. Environment and Planning A 40:18811900.

Cooke, B., and U. Kothari. 2001. The case for participation as tyranny. Pages 1-15 in B. Cooke and U. Kothari, editors. Participation: the new tyranny? Zed Books, London, UK.

Cornwall, A. 2002. Making spaces, changing places: situating participation in development. IDS Working Paper 170, Institute of Development Studies, Brighton, UK.

Dietz, T., and P. C. Stern, editors. 2008. Public participation in environmental assessment and decision making. Committee on the Human Dimensions of Global Change, National Research Council of the National Academies. [online] URL: http://books.nap.edu/openbook.php?record $\mathrm{id}=124$ 34\&page=R1.

Fernandez-Gimenez, M. E., H. L. Ballard, and V. E. Sturtevant. 2008. Adaptive management and social learning in collaborative and communitybased monitoring: a study of five community-based forestry organizations in the western USA. Ecology and Society 13:4. [online] URL: http://www.ecolog yandsociety.org/vol13/iss2/art4/.
Goffman, E. 1959. The presentation of self in everyday life. Anchor, Garden City, New York, USA.

Gonzalo-Turpin, H., N. Couix, and L. Hazard. 2008. Rethinking partnerships with the aim of producing knowledge with practical relevance: a case study in the field of ecological restoration. Ecology and Society 13:53. [online] URL: http://w ww.ecologyandsociety.org/vol13/iss2/art53/.

Goodwin, P. 1998. 'Hired hands' or 'local voice': understandings and experience of local participation in conservation. Transactions of the Institute of British Geographers 23:481-499.

Hajer, M. A. 2005. Setting the stage, a dramaturgy of policy deliberation. Administration and Society 36:624-647.

Hajer, M., and S. Kesselring. 1999. Democracy in the risk society? Learning from the new politics of mobility in Munich. Environmental Politics 8:1-23.

Hendriks, C. M., J. S. Dryzek, and C. Hunold. 2007. Turning up the heat, partisanship in deliberative innovations. Political Studies 55:362383.

Henkel, H., and R. Stirrat. 2001. Participation as spiritual duty; empowerment as secular subjection. Pages 168-184 in B. Cooke and U. Kothari, editors. Participation: the new tyranny? Zed Books, London, UK.

Innes, J. E., and D. E. Booher. 1999. Consensus building and complex adaptive systems. Journal of the American Planning Association 65:412-423.

Innes, J. E., and D. E. Booher. 2004. Reframing public participation: strategies for the 21 st century. Planning Theory and Practice 5:419-436.

Janis, I. L. 1972. Victims of groupthink. Houghton Mifflin, New York, USA.

Kabeer, N. 1996. Reversed realities: gender hierarchies in development thought. Kali for Women, New Delhi, India.

Kesby, M. 2007. Spatialising participatory approaches: the contribution of geography to a mature debate. Environment and Planning $A$ 39:2813-2831. 
Kohn, M. 2000. Language, power and persuasion: toward a critique of deliberative democracy. Constellations 7:408-429.

Kothari, U. 2001. Power, knowledge and social control in participatory development. Pages 139152 in B. Cooke and U. Kothari, editors. Participation: the new tyranny? Zed Books, London, UK.

Kuper, M., M. Dionnet, A. Hammani, Y. Bekkar, P. Garin, and B. Bluemling. 2009. Supporting the shift from state water to community water: lessons from a social learning approach to designing joint irrigation projects in Morocco. Ecology and Society 14:19. [online] URL: http://www.ecologyandsociety. org/vol14/iss 1/art19/.

Lawrence, A. 2006. 'No personal motive?' Volunteers, biodiversity and the false dichotomies of participation. Ethics, Place and Environment 9:279-298.

Leach, M., and I. Scoones. 2005. Science and citizenship in a global context. Pages 15-38 in M. Leach, I. Scoones, and B. Wynne, editors. Science and citizens: globalization and the challenges of engagement. Zed Books, London, New York.

Leach, M., I. Scoones, and B. Wynne. 2005. Introduction: science, citizenship and globalization. Pages 3-14 in M. Leach, I. Scoones, and B. Wynne, editors. Science and citizens: globalization and the challenges of engagement. Zed Books, London, New York.

Leeuwis, C., and R. Pyburn, editors. 2002 Wheelbarrows full of frogs. Social learning in rural resource management. Van Gorcum, Assen, The Netherlands.

Ministerie van Landbouw, Natuurbeheer, en Visserij (LNV). 2000. Natuur voor mensen, mensen voor natuur: Nota natuur, bos en landschap in de 2le eeuw. Ministerie van Landbouw, Natuurbeheer, en Visserij, Den Haag.

Lynam, T., W. De Jong, D. Sheil, T. Kusumanto, and K. Evans. 2007. A review of tools for incorporating community knowledge, preferences, and values into decision making in natural resources management. Ecology and Society 12:5. [online] URL: http://www.ecologyandsociety.org/vol12/iss1/ art5/.
McCarthy, J. 2005. Devolution in the woods: community forestry as hybrid neoliberalism. Environment and Planning A 37:995-1014.

McComas, K. A., J. C. Besley, and C. W. Trumbo. 2006. Why citizens do and do not attend public meetings about local cancer cluster investigations. The Policy Studies Journal 34:671-698.

Mohan G., and K. Stokke. 2000. Participatory development and empowerment: the dangers of localism. Third World Quarterly 21:247-268.

Mosse, D. 2001. 'People's knowledge', participation and patronage: operations and representations in rural development. Pages 16-35 in B. Cooke and U. Kothari, editors. Participation: the new tyranny? Zed Books, London, UK.

Mouffe, C. 1993. The return of the political. Verso, London, UK.

Nuijten, M. 1992. Local organisation as organising practices: rethinking rural institutions. Pages 189207 in N. Long and A. Long, editors. Battlefields of knowledge: the interlocking of theory and practice in social research and development. Routledge, London, UK.

O'Neill, J. 2001. Representing people, representing nature, representing the world. Environment and Planning C 19:483-500.

Owens, S. 2000. 'Engaging the public': information and deliberation in environmental policy. Environment and Planning A 32:1141-1148.

Parfitt, T. 2004. The ambiguity of participation: a qualified defence of participatory development. Third World Quarterly 25:537-556.

Pellizzone, L. 2001. The myth of the best argument: power, deliberation and reason. British Journal of Sociology 52:59-86.

Röling, N. G., and M. A. E. Wagemakers, editors. 1998. Facilitating sustainable agriculture: participatory learning and adaptive management in times of environmental uncertainty. Cambridge University Press, Cambridge, UK.

Selfa, T., and J. Endter-Wada. 2008. The politics of community-based conservation in natural resource management: a focus for international 
comparative analysis. Environment and Planning A 40:948-965.

Stringer, L. C., A. J. Dougill, E. Fraser, K. Hubacek, C. Prell, and M. S. Reed. 2006. Unpacking "participation" in the adaptive management of social-ecological systems: a critical review. Ecology and Society 11:39. [online] URL: http://www.ecologyandsociety.org/vol11/iss2/art39/

Turnhout, E. 2003. Ecological indicators in Dutch nature conservation: science and policy intertwined in the classification and evaluation of nature. Aksant, Amsterdam, The Netherlands.

Turnhout, E., and M. W. Van der Zouwen. 2010. 'Governance without governance': how nature policy was democratized in the Netherlands. Critical Policy Studies 4(40):344-361.

Van Asselt, M. B. A., and N. Rijkens-Klomp. 2002. A look in the mirror: reflection on participation in integrated assessment from a methodological perspective. Global Environmental Change 12:107-180.

Van Bommel, S. 2008. Understanding experts and expertise in different governance contexts: the case of nature conservation in the Drentsche Aa area in the Netherlands. Dissertation. Wageningen University, The Netherlands. [online] URL: http://edepot.wur.n $\underline{1 / 122058}$.

Van Bommel, S., and N. Röling. 2004. The Drentsche Aa area in the Netherlands. SLIM Case Study Monograph. Open University, Milton Keynes.

Van Bommel, S., N. G. Röling, N. Aarts, and E. Turnhout. 2009. Social learning for solving complex problems: a promising solution or wishful thinking? A case study of multi-actor negotiation for the integrated management and sustainable use of the Drentsche Aa area in the Netherlands. Environmental Policy and Governance 19:400412.

Wagemans, M. 2002. Institutional conditions for transformations. A plea for policy making from the perspective of constructivism. Pages 245-256 in C. Leeuwis and R. Pyburn, editors. Wheelbarrows full of frogs. Social learning in rural resource management. Van Gorcum, Assen, The Netherlands.
Webler, T., and S. Tuler. 2002. Unlocking the puzzle of public participation. Bulletin of Science Technology Society 22:179-189.

White, S. C. 1996. Depoliticising development: the uses and abuses of participation. Development in Practice 6:6-15.

Wollenberg, E., B. Campbell, E. Dounias, P. Gunarso, M. Moeliono, and D. Sheil. 2008. Interactive land-use planning in Indonesian rainforest landscapes: connecting plans to practice. Ecology and Society 14:35. [online] URL: http://w ww.ecologyandsociety.org/vol14/iss1/art35/.

[1] A national landscape differs slightly from the originally intended national park. Both put conservation values first, but a national landscape allows more room for the preservation and development of cultural landscape values. 